\title{
Sacred groves as potential ecotourism sites at Tolon and Diare in Northern Region, Ghana
}

Benjamin Makimilua Tiimub ${ }^{1 *}$, Richard Amankwah Kuffour ${ }^{2}$, Richard Wonnsibe Tiimob ${ }^{3}$, Cletus Ankrah Kuuyeni ${ }^{4}$, Ernestina Laatman Tiimob ${ }^{5}$, \& Elisha Nyannube Tiimob ${ }^{6}$

Department of Environmental Health and Sanitation Education, University of Education, Winneba, Ashanti-Mampong Campus, Ghana ${ }^{1,2,4}$

Science Department, Savelugu SHS, Ghana Education Service, Tamale, Northern Region ${ }^{3}$

Business Senior High School (BISCO), Tamale, N.R. Ghana ${ }^{5}$

Department of Ports and Shipping, Regional Maritime University, Nungua-Accra, Ghana ${ }^{6}$

benmakimit@yahoo.com ${ }^{1 *}$, rakuffour@gmail.com ${ }^{2}$, wtiimob@gmail.com ${ }^{3}$, kuuyenica@yahoo.com ${ }^{4}$, tinalaat@gmail.com ${ }^{5}$, elishadat1998@gmail.com ${ }^{6}$

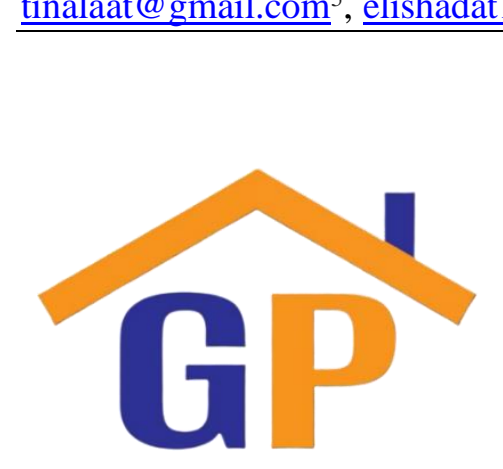

Article History

Received on 12 September 2020

Revised on 4 October 2020

Accepted on 6 October 2020

\section{Abstract}

Purpose: Relic plant communities commonly referred as "sacred groves" in Ghana and comparatively anywhere are ecologically, genetically important resources indigenously protected as "abodes of gods or ancestral habitats" through traditional or religious beliefs and taboos. This study mainly evaluated the potentials of sacred groves for development as tourist sites at Tolon and Diare in the Northern Region of Ghana.

Research methodology: Data was collected using semi structured interview questionnaire aided by vegetation survey, observational field walk through the Jaagbo and Tindangung Sacred Groves to screen natural features of the destinations and determine its potential for ecotourism.

Findings: Potential areas for visitor amateurism such as the wonderful baobab tree, crocodile pond, misty stone bird sanctuary, were identified in both groves. About 220 different species of plants were identified in the entire groves. The study further discovered that with effective management measures in place, the ecotourism potentials of these sacred groves will optimize if developed to attract visitors and generate income for sustainable socio-economic development of the adjoining communities in northern Ghana.

Limitations: Although the target population was above 200 people, relatively small sample size $(\leq 36 \%)$, could be chosen since the opinion leaders considered the groves as sacred and were less prepared to divulge information about them. Islam and Christianity rather counteracted certain beliefs of the traditional people who adopted local measures to enhance sustainability of these sites for ecotourism functions.

Contribution: The study advocates the adoption of bylaws to promote sustainable management of the sacred groves for sustainable benefits.

Keywords: Jaagbo, Tindangung, Sacred grove, Crocodile pond, Bird sanctuary, Traditional bylaws, Land use plan

How to cite: Tiimub, B. M., Kuffour, R. A., Tiimob, R. W., Kuuyeni, C. A., Tiimob, E. L., \& Tiimob, E. N. (2020). Sacred groves as potential ecotourism sites at Tolon and Diare in Northern Region, Ghana. Journal of Sustainable Tourism and Entrepreneurship, 1(3), 195-215. 


\section{Introduction}

In Ghana, human activities have impacted on the Northern Guinea Savanna Vegetation (NGSV) to such an extent that few climax representative plant communities now exist. Some of these relic plant communities commonly referred as sacred or fetish groves have been protected by the indigenous people as "abodes of the gods or ancestral habitats" through traditional or religious beliefs and taboos (Telly, 2006). Sacred groves of Ghana and comparatively anywhere else are ecologically and genetically important (Ziegler, 2019; Nganso et al., 2012). Sacred groves are abodes of rare, endemic and endangered species of fauna and flora and also serve the function of preserving pretty biological diversity (Salifu, 2013). The Sacred groves of Kerela in India for instance is known to have preserved more than 800 species of plants out of which 150 species are of medicinal values and $40 \%$ are endangered (Polidor, 2004; Swamy et al., 2003). It has been strongly advocated that in rural areas of a region, protected areas are also not untouched from anthropogenic pressures and have human presence within the landscape in India. In Kedarnath Wildlife Sanctuary, 12 villages are located inside the Sanctuary while 161 are situated along the southern boundary, whose inhabitants depend substantially on its resources. Fringe forests of the sanctuary and community forests within villages constitute indispensable source of indirect earning, meeting households' consumption requirements of timber and firewood extracts and non-wood such as fodder, leaf litter, and forest products and as pastures for livestock grazing (Manral, 2018).

According to the Ghana Tourist Board (GTB), Domestic tourism generates economic benefits to local areas and helps redistributes income from urban to rural areas. More importantly, domestic tourism offers the opportunity for residents to fully appreciate their own culture and environmental heritage and to participate in recreational activities UNDP / WTO (1995). Mohapatra et al., (2017), also reported that sacred grove of Bonai, serve as ecotourism centre and still preserves different plant species used for curing many diseases. The high promising potentials of sacred groves underscores its development urgency not only to attract tourists but also as a means to preserve biodiversity and promote novelty in nature's scientific research and reporting systems once it significantly promotes the fight against dynamics of extinction debt across various taxonomic groups (Halley et al., 2016). Sacred groves represent the best option for protecting the biodiversity of forests in Ghana. In conserving biodiversity by other means, national conservation areas for example, have been implicated with complicated impacts. As a matter of significance, sacred groves may be used as land marks for developing new policy indicators in strategic environmental impact evaluations of protected area networks (Hausner, 2017). In the case of the Kakum conservation area in Ghana for instance, establishment of the park had the potential to reduce access to natural resources, destroy alternative local jobs, and facilitate negative wildlife interactions with local farms, hence, requiring periodic environmental and social assessments to forestall ills (Cobbinah et al., 2015). It is promising that sacred groves as protected areas could certainly be developed into parks or natural gardens as well as eco-tourist sites which may be a way to help preserve their biodiversity, create an avenue for recreation and serve as a source of income for the communities (Bicknell et al., 2017). Developing sacred groves into parks to promote ecotourism is a good measure to counteract encroachment and residential developments at the buffer zones by emerging communities (Brambilla and Ronchi, 2016). Protected areas also serve as a means for monitoring land use changes in biodiversity conservation hotspot areas (Bailey et al., 2016). In some places it even serves as a natural herbal pharmacy (Oyebamiji, $\underline{2019)}$.

However, most traditional authorities around protected areas in Puerto Rico wrongly perceive that sacred groves are houses of non-existent or evil spirits where sacrifices are offered to make the gods, ancestors and the community members wrongly impressed and thus, should be substituted for urban construction (Castro-prieto et al., 2017). But others feel it is justifiable 
that, apart from the reality that traditionally protected areas or sacred groves serve as holy or spiritual places; they are also abodes of the gods, rare plants and animals which ought to be strictly conserved for posterity reasons in both social and nature's perspectives (Ferraro and Pressey, 2015). Three groups of protected areas are identified in Ghana, in forms of - i. sacred groves, ii. forest reserves, and iii. wild life reserves. According to the custodians, most of the protected areas have potentials which when well developed, will become great ecotourism centres although, little or no attempt has been made to develop them. Telly (2006) made an attempt by writing on the topic "developing the Jaabgo sacred grove as an eco-tourism centre", but all his efforts proved futile for more than two past decades until recently that some attention is directed at it by the Government of Ghana (Osei-Bonsu, 2016). This study candidly evaluated the potentials of some of the well noted sacred groves in the Northern Region and how they can be developed into eco-tourist sites. The research verified potentiality of the understudied sacred groves for development as ecotourist sites by specifically identifying - $i$. the custodian/ownership of sacred groves, ii. interest areas of visitors for tourism attraction to the groves, iii. the value of sacred groves to adjoining communities as well as, iv. unique features of the groves for ecotourism prospection.

\section{Literature Review}

\subsection{Tourism in Ghana}

Tourism is one aspect of leisure which usually, but not invariable, involves some expenditure by the participant. It is the sum of the phenomena and the relationships arising from the travel and stay of non-residents, in so far as it does not lead to permanent residential status and not connected to any earning activity by the travelers (McGuigan, 2018). Ecotourism however is illustrated as tourism directed towards exotic natural environments especially intended to support conservation of natural resources. In general, ecotourism focuses on an ecological area and seems to involve the local people, tourists and tour operators to ensure sustainable amateurism with economic benefits and environmental protection (Bailey et al., 2016). According to the World Tourism Organization, a United Nation's Agency that serves as a global forum for tourism policy, worldwide international tourism grew by $\geq 5.5$ percent between 2014-17. International tourism is expected to surpass 1.6 billion arrivals by 2020, which does not include domestic tourism (Fulton, 2018).

Since the late 1980's, tourism has received a considerable attention in the economic development strategy of Ghana. The number of tourist arrivals and amount of tourist expenditure have steadily increased while both public and private investment activities in various tourism sub-sectors have grossly expanded (Osei-Bonsu, 2016). The GoG established Tourism Development Board in 1993 to underscore its commitments towards tourism development with assistance from the United Nations Develop Programme (UNPP) and the World Tourism Organization (WTO). The GoG then prepared a 15-year Tourism Development Plan from 1996-2010 with significant modifications that promote progressive benefits (OseiBonsu, 2016). Osei-Bonsu further describe tourism as "a powerful economic system specially driven and increasingly impacting on the protected areas of Ghana's ecosystems. The rationale for tourisms development is at two levels: i. macro or national and regional and, ii. micro or local district and community levels. At the macro level, tourism is expected to promote economic growth by generating foreign exchanges as well as revenue from services providers to government. At the micro level, tourism is expected to facilitate job creation, income and revenue distribution which should improve the quality of life of district and community residents (UNDP / WTO, 1995). In global perspective, tourism in particular has been identified as a viable option for attainment of sustainable development while ecotourism presents developing countries with growing opportunities for enhancing resource conservation and economic growth through local networking of enterprises springing from ecotourism functions 
(ATM, 2015). Some ecotourism activities carried out in sacred groves include photography, pleasure walking, cycling, jogging, sport fishing and cultural tourism [movements of persons for essentially cultural motivations such as study tours, performing arts and cultural functions, travel to festivals and other social events, visits to sites and monuments, travel to study nature, folklore or art, and pilgrimages].

\subsection{Tourism, culture and the environment}

There are cultural and environmental reasons for tourism development in Ghana and the country has cultural resources and values that can be rehabilitated and preserved through tourism (ATM, 2015). Among these are the three world heritage forts and castles in Cape Coast and Elmina which are undergoing restoration for the development of ethnic tourism UNDP / WTO (1995). Expanding population has placed increased pressure on the environment and has necessitated conservation of the ecosystem through tourism enterprises such as establishment of National Parks, and other places of special interest including the Aburi Botanical Garden, Boti Falls, Paga Crocodile Pond, the Mole National Park and some sacred groves. The 15-year Tourism Development Plan by the GoG identified several National Park sites in each of the ten regions (Osei-Bonsu, 2016). These resources have been gradually developed under sustainable long-term plans to form the basis for the country's ecotourism component of the tourism industry (Hoff \& Overgaard Planning Consultants,1974).

\subsection{Tourist sites in Ghana}

Almost every country in the world has some form of natural resources that can be developed to sustain the global tourism industry (Bicknell et al., 2017). Ghana on its part, is seriously developing her ecotourism potentials and has had a sustained annual growth rate of $12 \%$ in tourist revenue of which ecotourism plays a substantial role. There are a lot of potential tourist sites in Ghana. Some have been developed into tourist sites (traditional tourist site) while others are still under development. Some of the recent traditional tourist sites include the Paga Crocodile Pond, Laribanga Historic Mosque, Kintampo Water Falls, and community-basedsacred groves. Ghana's ecotourism programme currently focuses on the Central Region, which include the Kakum National Park with its Canopy walking way, which is the first of its prestigious kind in Africa (World Bank Report, 2017). According to the Ghana Tourist Board, Paga Crocodile Pond has a lot of crocodiles and serves as an ecotourism centre. Aburi Botanical Gardens and the Mole National Park have different indigenous and exotic fauna and flora diversity. Examples include elephants, antelopes, monkeys, lions, leopards, birds. In some cases, visitors are allowed to use binoculars for viewing the wild animals from a distance (Mole National Park, 2015).

\subsection{Historical concept of conservation through establishment of parks}

The 1990s brought in its wake considerable number of activities in the development of projects and programmes in the forestry sector of Ghana's economy. Attention was focused on community involvement in forest management. From the years 1990 to 1994, the GoG through the International Development Agency (IDA) supported the Forest Resource Management Project (FRMP), which systematically evaluated its forest and wild life resources and also assessed the capacity of the sector department to face the challenges of present and future generations. The evaluation involved such wild life reserves as: Forest Reserves Sanctuaries, National Parks and some prominent sacred groves. Globally, there has been a trend to move from strict regulatory conservation to adopt approaches that recognize the importance of rural people in the conservation of the forest and its resources (World Bank Report, 2017). In Ghana and some African countries, this has resulted in several national programmes aimed at 
conserving natural resources through the empowerment of rural communities. The concept of community conservation as earlier explained by Barrow (1997) entails:

i. The flexible management of resources with local people and benefits sharing mechanisms to enhance conservation and improve the quality of life of the people.

ii. The sustainable utilization of the natural resources within a community by the people themselves.

iii. Community initiative aimed at sustainable utilization of their common resources.

It is can be considered that this same concept, though not documented, has been the basis for the establishment of such community based natural resource conservation systems as the sacred groves in many parts of the world (Ziegler, 2019). Over 89\% of sacred groves in Ghana serve as water sheds for catchment areas where they protect sources of drinking water. So far, about $1.5 \%$ of Ghana's land is covered by some 2000 sacred groves (Salifu, 2013; Anane, 2002). Such protected areas which are community owned, afford sanctuary for breeding populations of birds that control insects and mammal pests in agricultural areas. Bats, which roost and breed in reserves may range far beyond their boundaries pollinating fruits and trees in the surrounding areas (Shaw, 2018).

Largely, national parks play important roles in nation development and conservation of nature. These roles range from recreation, education and scientific research to protection of sites and objects of cultural and historical heritage. Besides, establishment of national parks helps to protect fauna and flora against over exploitation (Osei-Bonsu, 2016). Also, the presentation of flora on steep slope protects the natural landscape against environmental degradation and thus, enhances the beauty of the environment. National parks also provide opportunities to scientists to conduct research and students to explore and appreciate nature. National parks protect sites and objects of cultural heritage. For example, Circeo National Park in Italy was created to conserve ancient Roman artifacts and the remains of Emperor Domitian's place dates from the first century (Elbakidze et al., 2013). According to Asiedu (2005), the establishment of parks and gardens has helped to conserve the ecosystem in Ghana. A park as he explained is an area especially reserved, acquired, controlled, preserved and managed primarily for recreation or preservation of natural fauna and flora. It includes special areas of natural wildlife, areas of prehistoric significance, areas of rare flora for play and study, including sacred groves. Some examples of parks in Ghana include Ridge Square, PWD Square, Korle Lagoon, Suntress Park and James Owusu Botanical Gardens (IUCN, 2010). Generally, literatures point that, the main objectives of any the educational programs of ecotourism sites tracking since the 1930s include one or more of the following (ParkNet, 2003; Global Forest Watch (1995-2020):

i. simple, understandable interpretation of the major features of each park by means of field trips, lectures, museums, and literature.

ii. Emphasis upon leading the visitor to study the real thing(s) rather than utilizing secondhand information. Typical academic methods are avoided.

iii. Utilization of a highly trained personnel with field experiences, able to interpret to the public the laws of the universe as exemplified in the parks, and able to develop concepts of the laws of life useful to all target groups.

iv. A research program which will furnish a continuous supply of dependable facts suitable for use in connection with the educational program structured.

\subsection{Sacred groves in Ghana, Africa}

In Ghana, beliefs about groves include the perception that they are sacred homes of good spirits as well as dwarfs and the domain of gods or ancestors responsible for all the woes of mankind (Ziegler, 2019; Abbiw, 1990). Sacred groves may also be considered as specific forest areas vested with powers beyond those of humans: They are homes to mighty spirits that 
can take or give life. They may originate from a range of roots, which include sites linked to specific events; sites surrounding temples; burial grounds or cemeteries housing the spirits of ancestors; the home of protective spirits; the homes of deities from which priests derive their healing powers; homes of powerful animal and plant species; as rivers, rocks, caves and "bottomless" water holes; and sites for initiation of rituals (Ziegler, 2019; Possey, 1999).

Ghana has about 1,904 sacred groves ranging from 0.5 to 1,300 hectares (Forest Commission Act, 1990). In previous records it has been estimated that the nation loses between 22,000 ha and 75,000 ha of the forest land annually through permanent conversion into agricultural lands, logging, mining and quarrying, fuel wood cutting, urban settlement, bush fires and to a lesser extent through gathering of minor forest products. Estimates between 2011 and 2018 statistics indicates that Ghana losses a primary forest cover of 6,898.62 plant species representing 7.4\% of the total forest cover annually (Global Forest Watch, 1995-2020). Sacred groves are believed to have been in existence for a very long time. They are inherited property of the surrounding communities from their forefathers as fetish places. The groves are protected from any degrading activities (example, bush fires). Some communities even have bylaws enacted by the local people for its protection whilst others rely on the authority of the traditional elders for its protection thus resulting in the conservation of its biodiversity. "Tree cover threshold" has been used for defining the tree cover area. For example, $75 \%$ includes only areas with more than $75 \%$ tree cover, reflecting dense canopies whereas $10 \%$ includes all areas with up to $10 \%$ tree cover with sparse canopies (Appendix Table 1).

Additionally, the protected areas data on threatened species in Ghana as of 2017, according to the World Database on Protected Areas (WDPA) maintained by the United Nations Environment World Conservation Monitoring Centre (UNEP-WCMC) has been presented (Appendix Table 2). The tree cover data are also presented (Appendix Table 3), highlighting the substantial administrative areas in Ghana based on a definition of $30 \%$ tree cover. Areas with less than $30 \%$ canopy cover are excluded. Further reports of the Global Forest Watch (1995-2020), captures biodiversity data on reptiles, amphibians, birds, fishes, mammals and vascular plants based on Species count by taxa for Ghana from specific sources (Appendix Table 4). For consistency, all data for a given group comes from a single source. Amphibians (amphibiaweb); Reptiles (reptile-database); Fish: (fishbase); Birds (birdlife); Mammals (IUCN); and Plants (World Conservation Monitoring Centre of the United Nations Environment Programme (UNEP-WCMC). Additional information on the Conservation data elucidates threatened species in Ghana as of 2018, according to the IUCN Red List (Appendix Table 5).

Access to most sacred groves or forests by community members or foreigners are restricted by taboos, codes and customs, except some particular activities and on special occasions (Oyebamiji, 2019). Again, as is the case in most countries like China, wood gathering, hunting, wood chopping and cultivation are strictly prohibited in the sacred groves (Salifu, 2013; Possey, 1999). Over 89\% of sacred groves in Ghana serve as water sheds for catchment areas where they protect sources of rivers or streams. About $1.5 \%$ of Ghana's land is covered by some 2000 sacred groves and most of them are managed by strict nature conservation approach (Anane, 2002). For example, the Asuo stream has a sacred grove in Ashanti Region. This stream is believed to be inhabited by a beautiful goddess, a deity who is accordingly worshiped by the people with the water source carefully protected. The Buabeng Fiema monkey sanctuary which is considered sacred is rich in terms of diverse types and rare species of monkeys like the Black and White colobus and the Mona. The Malshegu sacred grove (Kpalvogu) and Tolon sacred grove (Jaagbo) in Northern Ghana contain different fauna and flora that are of great medicinal values to the communities. The biodiversity of Jaagbo and Malshegu sacred groves were first identified by the staff of Environmental Protection Agency (EPA) in 1992 with its unique potentials for ecotourism in collaboration with a UNESCO Co2020 | Journal of Sustainable Tourism and Entrepreneurship/ Vol 1 No 3, 195-215 
operative Integrated Project on Savanna Ecosystem in Ghana, (CIPSEG). Out of 220 species of plants identified in these groves, $60 \%$ were of great medicinal value to the local people and could serve as a gene pool for medicinal plants.

\subsection{Present position of sacred groves as tourist sites}

There are a lot of sacred groves in Ghana that have the potential to attract tourists or investors. Some of these groves have already being developed. For instance, the Kpalvogu sacred grove was developed as ecotourism site by the UNESCO-CIPSEG Project (Ziegler, 2019). The same CIPSEG Project has a well laid down plan to develop the Jaagbo and Tindangung sacred grove as ecotourism centres though it failed in the past (Global Forest Watch, 1995-2020). The Jaagbo and Tindangung sacred groves have enormous ecotourism potentials. The flora diversity such as Adansonia digitata, Parkia biglobosa, Combretum nigricans, Mitrangyna inermis, Azadirachta indica, the historic baobab and fauna such as the leopard, python, crocodiles in ponds, constitute valuable attraction sites to ecotourists (Salifu, 2013, Ziegler, 2019).

\subsection{Development of sacred groves as ecotourism centres}

Ecotourism is more or less a new term, which is used interchangeably with nature tourism. Many studies have not been carried out especially in the developing world, even though there have been reports of growing demand in developed countries (Bicknell et al., 2017). Gowdy (1997), reported that part of the value of ecotourism arises from geological features but later researchers intimated that much of it is due to biodiversity (Bailey et al., 2016). According to the IUCN (2010) a protected area is an area of land or sea especially dedicated to the safe preservation and maintenance of biological diversity and of associated cultural resources concurrently managed through legal means. Sacred groves are traditionally protected areas which ensure prudent use of natural resources. Protected areas such as sacred groves or forest reserves can be developed to enhance resource conservation and economic growth (Castro-prieto et al., 2017).

According to Ferraro and Pressey (2015) ecotourism creates menial jobs for local people as cooks or housekeepers at tourist lodges, tour guards as well as tour agents or operators. Whole communities have since benefited from part of the ecotourism income generated while researchers visit developed sacred groves for reasons such as recreation, information and research samples or specimens (Colvin, 1996). Chin (1993) outlined a procedure to be adopted for enhancing forest ecotourism. The protocol enlists that:

i. for forest ecotourism to be successful, involvement of the local people is a necessity. This includes the provision of services such as local foods, handicraft, culture and guide.

ii. safety of ecotourism areas should not be compromised. Hazardous areas should be identified and fenced off, while hazardous trees should be removed. Site facilities should constantly be checked to ensure safe ecotourism.

iii. inventory of the resource should be thoroughly tracked to determine the carrying capacity of visitors or limits of acceptable modifications.

According to experts from the Ghana Tourism Authority, the ultimate goal of evaluating the potentials of sacred groves is to develop and make them an attractive tourist destination by maximizing the opportunities derived from it in addition to National Parks (OseiBonsu, 2016). If the grove is well developed, the touristic aspect of this initiative could offer significant economic gain to the District Assemblies and local communities through income generation. The development of sacred groves as possible tourist sites could be one of the 
means to achieve the Sustainable development Goals (SDGs) set up by the governments, and this could be optimized through the adoption of one or a combination of the following:

i. construction of "action status" as symbols to signify and portray their gods and ancestors or powerful kings.

ii. Protection of grove ecosystems by preserving fauna and flora from destruction.

iii. Protection / preservation of special fauna and flora species in the grove to attract tourists.

\subsection{Ecological, environmental and social values of sacred groves}

Forests are the largest reservoir of plants and animals. They create and retain soil and affect productivity of agriculture and sustainability of businesses, regulate the quality of the atmosphere, the climate and the ecosystem and therefore help to maintain a more natural balance of the ecosystem over a wide area. Protected areas serve as sanctuary for breeding populations of bird that control insects and mammal pest on farm lands. Bats, birds and bees which discover their niches and breed in reserves may range far outside their boundaries pollinating arable crops and trees in the surrounding areas (Shaw, 2018). As earlier spelt out by Gelder \& O' Keefe (1995), conservation especially of weed biomass provides service functions such as soil fertility improvement, soil erosion control, water conservation, wind shelter, shading and weed control. Maintaining the natural vegetation within protected areas further ameliorates the effects of global warning by locking up carbons that would otherwise contribute to the build-up of atmospheric carbon dioxide (Baptista, 2014). Inhabitants close to protected areas are often privileged to enjoy quality environment which is cleaner, more beautiful and more peaceful than elsewhere (Hang et al., 2019).

Socially, conservation of natural resources seeks to foster sustainable rural livelihoods and helps alleviate poverty. This means more income will improve wellbeing and food security for the rural folks. Some protected areas may contain products that are useful to local communities and which may be harvested without any deterioration to the area itself (UNEP, 2012). Directly or indirectly, a protected area can enhance employment opportunities in a given region (Kuuder et al., 2013b). The spectacular natural environment and aggregation of species are considered scenic for provision of pleasure to visitors (Kuuder et al., 2013, Cobbinah et al., 2015). Protected areas have stimulated profitable domestic industries, hotels, restaurants, transport system and handicrafts businesses across the world (Hang et al., 2019).

Traditionally, some animals are strictly preserved by custom while others are killed for customary rites but it was earlier on hinted that as far as traditional laws are concerned, ecosystem preservation is the duty of all citizens (Asibey, 1996). Also, in certain areas, it is their religion and killing, touching or catching preserved wildlife is even prohibited. Such wildlife species are considered sacred because of the local folklore which enjoin them on the belief that they probably have the same ancestry as a people. Wildlife, forest reserves, watersheds and other natural features have been ancestrally conserved through superstitious beliefs and traditional bylaws (UNESCO, 2018).

\subsection{Value of sacred groves as protected areas for promotion of human culture}

It has been discovered that, in every human culture, wildlands with rich biodiversity are at the core of hallowed landscapes that contain or promote religious activities such for divine reflection, prayers, sacred events and camping sites (Verschuuren, 2019). Sacred lands are places where the usual activities of any society are limited, and people approach these places with respect, humility, and awe (Wuerthner, 2020). It has been found in every culture that has been reviewed that, high mountains are revered terrains. Mount Olympus was the home of the gods to the ancient Greeks. The Zoroastrian culture revered Mount Damāvand in Iran. Mount Fuji was venerated by the Shinto religion in Japan. Mount Sinai is central to Judaism traditions. 
The Incas of Peru thought mountains were portal to the Gods. Machapuchare was a sublime Nepalese mountain worthy of a long pilgrimage visit. Mount Kilimanjaro in Tanzania was fundamental to African tribal religious beliefs. The ancient Celts of the British Isles honored the forces of nature, and among their sacred mountains was Croagh Patrick in Ireland. The San Francisco Peaks were divine in the natural world of the Navajo. Closer to home is the Crow tribe's reverence for the Crazy Mountains by Livingston. Every culture has a way of mountain worship (UNESCO, 2018). In American culture, the hallowed landscapes feature prominently as well. Designated wilderness, national parks, and such public spaces are the new version of "sacred lands" (Wuerthner, 2020). Hence, some schools of thoughts have recently strongly advocated in support of preservation of the sacred lands of the greater Yellowstone ecosystem as an example to the rest of the world for promotion of unique cultural values among the Americans (Ostlie et al., 2020).

\section{Methodology}

\subsection{Study area}

Data was collected from two study areas in two Districts: Chirifoliyili-TolonKumbungu and Diare sacred groves in Savelugu-Nanton both in the Northern Region of Ghana. Chirifoliyili is $35 \mathrm{~km}$ away from the Northern regional capital (Tamale), while Diare is about $53 \mathrm{~km}$ away from it.

\subsection{Data collection and analysis}

The data was collected with the aid of a semi-structured questionnaire (refer to survey instrument in the appendix). A total of 40 questionnaires were administered in the two study areas. At Tolon, 20 questionnaires were administered covering Chirifoyili and other two farming communities: Kpanyili and Tindag. Fifteen (15) men and five (5) women were randomly selected based on their historical background as people who had lived in the community continuously between 6 months and two year and had demonstrated keen interest in the ongoing activities of the sacred groves for the interview. At Diare, out of twenty (20) people randomly interviewed, fifteen (15) were men and five (5) women. This random selection of respondents for the purposive survey was done with the help of the opinion leaders (Assemblymen, Queen Mothers and Chiefs) at the study areas who confirmed the ability and suitability of the respondents to suggest meaningful answers based on their informed statuses and exposure to the protected area activities at the household/community levels. More men were selected based on the proportion ratios of male: female who were exposed to the sacred groves based on frequency of visits they made to the place occasionally in a year. It was revealed from preliminary investigations that more males $(80 \%)$ higher than females were readily available and willing to volunteer information for the community-based studies. This favored the application of stratified random selection criteria that involved more males (15 at a time) as against fewer females ( 5 at a time) for the more inclusive and gender balanced study. The $100 \%$ retrieved questionnaire data were analyzed using Statistical Package for Social Sciences (SPSS Chicago version 16.0) software at the level of simple descriptive statistics. The frequencies of responses were transformed into percentages and fundamentally presented in tabular forms for easy interpretation of citizens, community development partners and public readers who would adopt the findings for further decision-making purposes. Some tangible factors limited prudence of decisions made along the studies. From preliminary cross-sectional verbal intearctions with the community members, many of those interviewed disclosed that a lot of known damages were caused to the groves such as:

i. illegal cutting down of trees from the grove for fuel wood and roofing purposes.

ii. Burning of the grove to hunt animals like rats, birds, grasscutters, lizards, squirrels, et cetera. 
iii. Over exploitation of certain wild fauna and flora species in the groves for medical purposes.

iv. Lack of co-operation among community members on how to protect and preserve the grove.

v. Dominance of Islam and Christianity in these areas which downgraded the works of traditional set ups tagging them as profane and incapable of rendering any support towards proper protection of the groves.

Hence, there was the need to limit the size of the participants at the interviews based on the preliminary findings in order to capture essential information and avoid any form of tension, bias reasoning and discriminatory responses.

\section{Results and discussion}

Out of 40 questionnaires administered 14 peoples representing 35\% were traditional believers, 20 peoples representing 50\% of them were Moslems, 5 representing $12.5 \%$ were Christians and 1 other person at $2.5 \%$ of the respondents were interviewed (Table 4.1). Four respondents

Table 4.1: Groups of respondents as a percentage of total people interviewed

\begin{tabular}{lcc}
\hline Religion of Respondents & Number of Respondents & Percentage (\%) \\
\hline Traditional believer & 14 & 35 \\
Moslem & 20 & 50 \\
Christian & 5 & 12.5 \\
Other & 1 & 2.5 \\
Total & $\mathbf{4 0}$ & $\mathbf{1 0 0}$ \\
\hline
\end{tabular}

Table 4.2: Educational level of respondents

\begin{tabular}{lcc} 
Educational Level & Number of Respondents & Percentage $(\boldsymbol{\%})$ \\
\hline Primary & 4 & 10 \\
Middle School & 5 & 12.5 \\
Nil & 31 & 77.5 \\
Total & $\mathbf{4 0}$ & $\mathbf{1 0 0}$ \\
\hline
\end{tabular}

who answered the questionnaires representing $10 \%$ had primary education, while 5 representing $12.5 \%$ had middle school leaving certificate and 31 making up to $77.5 \%$ of the entire subjects lacked formal education (Table 4.2).

Thirty-nine respondents further representing $97.9 \%$ intimated that history of the grove attract visitors while 7 respondents making $17.5 \%$ were sure the floral diversity attracted more visitors and 31 respondents corresponding to $79.5 \%$ posed that religious rituals carried in the grove enticed visitors (Table 4.3). The entire forty respondents constituting $100 \%$ intimated that the groves have medicinal uses although some $30(82.5 \%)$ of the entire subjects confirmed obtaining edible fruits and mushrooms as non-timber forest products (NTFPs) from the groves as additional benefits (Table 4.4). Out of the 40 subjects, 28 of them making $70 \%$ disclosed that the groves could be properly maintained by preventing people cutting trees from it while, 10 respondents suggested restrictions against indiscriminate bush burning and 2 persons representing $5 \%$ co-opted for other 
Table 4.3: Features of the grove that attract visitors in percentage

\begin{tabular}{llc}
\hline Things that interest Visitors & No. of Respondents & Percentage (\%) \\
\hline & 39 & 97.5 \\
History of the grove & 7 & 17.5 \\
Floral diversity of the grove & 31 & 79.5 \\
Religious rites carried in the grove & $\mathbf{4 0}$ & $\mathbf{1 0 0}$ \\
Total & & \\
\hline
\end{tabular}

Table 4.4: Value / uses of plants species in responses to percentage

\begin{tabular}{lcc}
\hline Value / Uses of plant in the Grove & No. of Respondents & Percentage (\%) \\
\hline Medicinal Purposes & 40 & 100 \\
Fruits and mushrooms derived as food & 30 & 82.5 \\
Total & $\mathbf{4 0}$ & $\mathbf{1 0 0}$ \\
\hline
\end{tabular}

Table 4.5: Maintenance of the grove by respondents in percentage

\begin{tabular}{lll}
\hline $\begin{array}{l}\text { How do you maintain plant and } \\
\text { animals in the grove }\end{array}$ & No. of Respondents & Percentage (\%) \\
\hline Preventing people from cutting the grove & 28 & 70 \\
Avoid burning the grove & 10 & 25 \\
Others (bylaws, court ruling, punishments) & 2 & 5 \\
Total & $\mathbf{4 0}$ & $\mathbf{1 0 0}$ \\
\hline
\end{tabular}

Table 4.6: Number of respondents who encourage grove development as eco-tourist sites

\begin{tabular}{lccc}
\hline $\begin{array}{l}\text { Will you encourage grove } \\
\begin{array}{l}\text { (\%) } \\
\text { Development to attract tourist? }\end{array}\end{array}$ & Response & No. of Respondents & Percentage \\
\hline $\begin{array}{l}\text { Do visitors visit the grove? } \\
\begin{array}{l}\text { Will you encourage the groves } \\
\text { development as a tourist centre? }\end{array}\end{array}$ & Yes & 40 & 100 \\
$\begin{array}{l}\text { Others who disagreed due to religion } \\
\text { and other undisclosed sentiments, opting }\end{array}$ & No & 37 & 92.5 \\
\hline
\end{tabular}

interventions such as bylaws, courts ruling and punishments - issued against those tampering with sacred groves as the ways forward for sustainable management of ecotourism resources (Table 4.5). Forty respondents representing $100 \%$ admitted that visitors come to the groves while 37 making up $92.5 \%$ of the subjects intimated the groves should be developed into ecotourism sites. Contrarily, 3 respondents comprising $7.5 \%$ disagreed to development of the groves as ecotourism sites based on some religious and other undisclosed sentiments (Table 4.6).

\subsection{Religion and culture of the people}

The study showed that $50 \%$ of the respondents were Moslems, $35 \%$ traditional believers and $13 \%$ Christians. It is of clear note that the combined $63 \%$ of Moslems and Christians do not attach any religious value to the groves and hence were adamant about developing it into ecotourism destinations for community members to be gainfully employed. This was in direct contrast to the $35 \%$ of traditional believers who attached significant values to the sacred groves. Their beliefs were that such places are abodes of their gods and ancestors so, developing them will not auger well for their gods or natural emotions and superstitions, backed by recent 
findings which discourage acts that tamper with the naturalness of sacred groves (Ostlie et al, $\underline{2020)}$

\subsection{Unique features of sacred groves}

The Tindangung sacred grove in Saveligu-Nanton District also has a mystic stone at the middle of the shrine, monitor lizards, pythons and other wildlife that gallivant the forest. However, of the total respondents interviewed in both communities about $97.5 \%$ of them mentioned that the histories of the sacred groves attract people while $79.5 \%$ felt it was rather the routine religious rituals performed that attract visitors. A smaller percentage $(7.5 \%)$ of respondents also posited that it was rather the floral diversity components of these sacred groves which attracted some tourists or researchers. The uniqueness of flora for touristic attraction has been confirmed recently elsewhere by Wuerthner and Hang et al., as previously highlighted by Cobbina et al., in Ghana (Wuerthner, 2020; Hang et al., 2019; Cobbinah et al., 2015). According to past reports, the objective for establishing Bezamohofaly and Andahalala projects in 1977 was to protect reverine and spiny bush forests in Southwestern Madagascar to enhance ecotourism (Sheila, 1993). This current study similarly focused on expanding ecotourism by conserving the unique potential features of the sacred groves to promote local tourism. Both Jaagbo and Tindangung sacred groves were intimated with unique features which significantly showcase their potentials for sustainable ecotourism development ceteris paribus. The Jaagbo sacred grove for instance has about 220 different species of plants. Besides, paths have been created leading to certain adventitious points in the grove such the crocodile pond, bird sanctuary and historic baobab tree that is longitudinally imprinted with horse foot (Telly, $\underline{2003)}$.

\subsection{Benefits of the sacred groves}

In Asian sacred sites for instance, many of the community members placed great values on the sacredness of their groves due to some associated benefits and categorized them into two: firstly, the environment and the second, social (Verschuuren, 2016). In line with these value system ideologies, the tailored results confirm that about $60 \%$ of respondents in this Ghanaian study intimated that the groves offer them rain and protection against strong wind slides while $40 \%$ claimed the groves were indirect sources of derived income from the tourists who patronize them. These groves were further attributed as healing sources once about $60 \%$ of medicinal plants or animals are obtained from it to treat various diseases (almost all the respondents interviewed intimated the groves were of direct medicinal value to them). These groves further constituted spiritual grounds for performance of traditional sacrifices to localized ancestral gods of the lands. About $83 \%$ of the community members accentuated that the groves provide them with fruits which serve as asynchronous sources of food security for the people to break hunger pulses. Their beliefs were pinned towards quick conversion of the groves to ecotourism centres so that better care and management could be devoted to conserve both the medicinal and non-medicinal plants species. Examples of medicinal tree species within the groves are Alstonia boonie and Tamarindus indica. These species were highlighted by $80 \%$ of the respondents to be efficacious towards local treatment of stomach upset and dysentery and were used to assist in the delivery of placenta during labour when the barks of trees are processed. The findings ultimately confirmed that sacred groves classically provide a number of benefits to local indigenes in the communities and entire nations as obviously intimated by various experts (Halley et al., 2016; Bicknell et al., 2017; Brambilla and Ronchi, 2016; Bailey et al., 2016 and Oyebamiji, 2019). These inexhaustive benefits according to expressions of the subjects interviewed were summarized as follows:

i. it is used as a research base for students and researchers in forestry and natural resource studies (38 respondents out of 40 posited totaling 95\%); 
ii. it promotes cultural values once it is often used as special burial grounds, religious or spiritual functions for some members of the community (29 out of 40 respondents sided with the idea, making $72.5 \%$ );

iii. its ecological role promotes purification and stabilization of the environment through protection of water bodies, provision of habitat for conservation of wildlife species and natural purification of polluted systems by phytoremediation, natural decomposition and bioremediation of air, water and soil pollutants (100\% responded yes to the idea);

iv. the grove also permits limited collection of non-timber forest products such as medicinal plants or animals (94\% of respondents agreed to it).

\subsection{Management and maintenance of the grove}

Majority (90-95\%) of the respondents in this survey attested that successful traditional means of sacred groves protection was attributable to factors such as: use of the groves to promote ancestral worship apart from rendering sacrifice to the gods. The use of taboos also restricts the level of activity in the grove to some particular days in the week. Despite all these claims, most respondents remarked on the need to ensure proper conservation of fauna and flora at the groves. For instance, $75 \%$ of the subjects suggested maintenance and non-cutting of wood in the grove while $25 \%$ posited that avoidance of bush burning were generally crucial measures of sustainability import. About $92.5 \%$ of the community members opined to development of the groves into a tourist centres as the best alternative. According to them, it serves as the way forward to enhancing sustainable utilization and management of natural resources. These opinions also linked up appropriately with conservation principles once the findings corroborated well with historic development agenda of Ghana. It has been since 1887 that the Colonial government set up steps towards sound conservation of certain forest areas of the Gold Coast. The forest reserves established were intended to protect agriculture land from erosion, maintain equilibrium in climatic conditions and sustain river sources. However, most sacred groves laid outside the confines of the forest reserves and so are perceived vulnerable to both natural and anthropogenic disturbances (Nganso et al., 2011; Telly, 2003). Traditionally and over the past two centuries, sacred groves have experienced environmental protection via cultural belief, byelaws and occasionally external scientific or management interventions from NGOs and International Organizations such as GACON and UNESCO under CIPSEG Project of 1992 (UNEP, 2012).

\section{Conclusion}

Much study has not been conducted to evaluate the potentials of sacred groves that can be conserved and developed into sustainable ecotourism centres in Ghana as previewing at the time of this study. However, local communities and some NGOs have made attempts to prevent destruction and degradation of potential fauna and flora species in groves. Sacred groves, by virtue of their cultural association with the local people have intrinsically imbued in them, a natural desire to conserve the exhibitive potentials. The success rate of conserving the potentials of sacred groves that can be converted into ecotourist sites significantly depends on the involvement and co-operation of the local people. But in both practical and theoretical terms, participation of the local people according to various case studies is crucial for linking environment and ecotourism to socio economic development agenda of local communities, districts, regions and whole nations (UNESCO, 2017). This postulated idea has been confirmed by this current results whereby about $93 \%$ significant majority of the subjects attested that the sacred groves understudied should be developed into key national ecotourism sites to tentatively harness scientific, educational, business and socio-cultural benefits. Some chiefs and their elders with the UNESCO-CIPSEG project and Ghana Association for Conservation of Nature formed the Sacred Grove Management Committee (SGMC) towards the protection 
and sustainable management of local forests and sacred groves. It is therefore hoped that bylaws enacted by the SGMC will salvage and accelerate the conservation of fauna and flora species in the groves that can be developed into ecotourism centres. Never the less, majority (> 50\%) of the community indigenes in a post study tour evaluation and feedback dissemination meeting further suggested that the groves should be innovatively landscaped by introducing different species of plants and fencing the peripheries to optimize its potentials for ecotourism functions in the long run.

\section{Limitations and countereffect}

Although the population of each of the study areas was above 200 people, only small sample size $(\leq 36 \%)$ could be selected because the opinion leaders considered the groves as sacred and were less prepared to divulge information about them. About $7.5 \%$ of the respondents actuated that despite the ascertainable potentials of the groves to be developed into ecotourism sites, it should not be done since it was likely to tamper with the stability of their gods and the ancestral spirits may get provoked. Although, the subjects valued the sacred groves based on the traditional and cultural regulations governing its protection, the religious sentiments of the indigenous Muslims and Christians churned to denigrate significant effects of actual traditional beliefs, totems and taboo systems that could otherwise herald or advance the sustainable implementation of target regulations to locally govern conservation initiatives. All the same, believers in these two religions (Islam and Christianity) were not so infamous in advocating for suitable modification of realistic approaches by adopting useful changes or collaborative initiatives that could propel the conversion of the groves into ecotourism destinations. These limitations were however counteracted by the persistent ideological theorem devised or imagined among the community members in support of the view that integrating management of the sacred groves with sustainable ecotourism development agenda will substantially benefit the adjoining communities in the long run.

\section{Recommendations}

The following recommendations have been proposed for consideration:

i. The diversity of plant and animal species should be improved through planting of harsh weather tolerant, multipurpose ideotype plant species and the introduction of adaptive wild animals.

ii. Once the groves are protected by traditional systems of management, any investment that will be well protected and utilized should consider partnering the local people.

iii. Community members should team up as a security force over the sacred groves to prevent intruders from causing any further destruction to its state of naturalness.

iv. Farmers or community members should be encouraged to establish wood lots outside the groves to serve as alternative energy sources. This will prevent them from solely relying on groves for firewood.

v. To counteract erroneousness, traditional bylaws should be enacted into the communitybased natural resource management plans to promote conservation of these sacred groves in line with future land use planning.

\section{Acknowledgements}

The authors appreciate the good work done by Mr. Musah Awal of Ghana Tourist Board for providing part of the reviewed literature guide. Sincere appreciation is kindly extended to the Chiefs of Tolon and Diare, Messrs. Dahamani Musah and Alhassan Abdulai, and their Elders for warmly welcoming and supporting the researchers in their communities to collect valid data from the respondents. 


\section{Authors Contributions}

Benjamin and Kuffour provided leadership guidance and funding to conduct the research with Cletus and Richard whiles Ernestina and Elisha reviewed aspects of the literature and updated references, all authors co-edited the article.

\section{References}

Abbiw, D. K. (1990): Useful Plants of Ghana: West African uses of wild and cultivated plants. Immediate Technology Publications, London. Pp. $14-17$

Anane, M. (2002): Religion and Conservation in Ghana: Implementation age 21 NGLS Publications. Pp. $19-24$.

Asibey, E. O. A. (1996): The case for wildlife conservation in Ghana. The Ghanaian Farmer. Pp. 66 -72 .

Asiedu J. (2005): Personal Communication: Staff of Environmental Protect Agency.

ATM [Africa Tourism Monitor] (2015). Unlocking Africa's Tourism Potential. 3(1), 2-56.

Bailey, K.M., Mccleery, R.A., Binford, M.W., Zweig, C., Bailey, K.M., Mccleery, R.A., Binford, M.W. and Zweig, C. (2016). Land-cover change within and around protected areas in a biodiversity hotspot. J. Land Use Sci., 11 (2016), pp. 154-176.

Baptista, S. R. (2014). Design and Use of Composite Indices in Assessment of Climate Change Vulnerability and Resilience. United States Agency International Development (USAID), Washington, DC (2014).

Barrow, E.G.C. (1997): Mole National Park: Potentials and Opportunities for Community conservation in Ghana. Oxford University Press Pp. $4-5$.

Bicknell, M.B. Collins, R.S.A. Pickles, N.P. McCann, C.R. Bernard, D.J. Fernandes, M.G.R. Miller, S.M.James, A.U. Williams, M.J. Struebig, Z.G. Davies, R.J. S. (2017). Designing protected area networks that translate international conservation commitments into national action. Biol. Conserv., 214, pp. 168-175

Brambilla, M. and Ronchi, S. (2016). The park-view effect: Residential development is higher at the boundaries of protected areas. Sci. Total Environ., 569-570 (2016), pp. 1402-1407.

Castro-prieto, J., Martinuzzi, S., Radeloff, V.C., Helmers, D.P., Quiñones, M., and Gould, W.A. (2017). Declining human population but increasing residential development around protected areas in Puerto Rico. Biol. Conserv., 209 (2017), pp. 473-481.

Chin, T. Y. (1993): Prospects of forest eco-tourism in peminsular Malaysia, the forest Journal of the Malaysian forest, volume 56 No. 1, 26-36.

Cobbinah, R. P., Black, R., Thwaites, R. (2015). "Biodiversity conservation and livelihoods in rural Ghana: Impacts and coping strategies." Environmental Development. 15. 79-93.

Colvin, J. G. (1996): Indigenous Eco-tourism: The capirona programme in Napo province, Ecuador, Journal of unasylven, English Edition 47 (187): 323 - 37.

Elbakidze, M., Angelstam, P., Sobolev, N., Degerman, E., Andersson, K., Axelsson, R., Höjer, O., and Wennberg, S. (2013). Protected area as an indicator of ecological sustainability? A century of development in Europe's boreal forest. Ambio, 42, pp. 201-214

Ferraro, P.J. and Pressey, R.L. (2015). Measuring the difference made by conservation initiatives: protected areas and their environmental and social impacts. Philos. Trans. R. Soc. B Biol. Sci., 370 (2015), p. 20140270.

Forest Commission Act (1990). Forest Commission Act (Act 571) of Ghana. Summary of components. Date of Gc efte notification: 10th September. Pages 1-18. 
Fulton, J. (2018). Tourism Vs. Eco-tourism. Travel tips. Leaf Group Updated March 21, 2018.

Gelder, P. \& O’ Keefe, N. (1995): Sacred Groves Threatened by Development: The Kaya Forest of Kenya, Cultural Survival Quarterly, Pp, $19-21$.

Global Forest Watch (1995-2020). Tree cover loss: Hansen/UMD/Google/USGS/NASA.

Administrative boundaries: Global Administrative Areas database (GADM), version 3.6. Mongabay.

Gowdy, J. M. (1997): The Value Biodiversity - Market, Society and Ecosystems, Journal of Land Economics Vol. 73 (1): 25 - 41.

Halley, J.M., Monokrousos, N., Mazaris, A.D., Newmark, W.D., Vokou, D. (2016). Dynamics of extinction debt across five taxonomic groups. Nat. Commun., 7 (2016), p. 12283.

Hang, W., Lee Saiful, L., and Abdullah, A., (2019). Framework to develop a consolidated index model to evaluate the conservation effectiveness of protected areas. Ecological Indicators. Volume 102, July, Pages 131-144

Hausner, V.H., Engen, S., Bludd, E.K. and Yoccoz, N.G. (2017). Policy indicators for use in impact evaluations of protected area networks. Ecol. Indic., 75 (2017), pp. 192-202.

Hoff \& Overgaard Planning Consultants. (1974): Tourism ion Ghana Development Guide 1975 1990. A master feasibility study presented to the government of Ghana, Copenhagen: The Danish International Development Agency. Pp. 6- 7.

International Union on Conservation of Nature (IUCN)/Programme Afrique Centrale et Occidentale (PACO) (2010). Parks and reserves of Ghana: Management effectiveness assessment of protected areas. Ouagadougou, BF: UICN/PACO.

Kuuder, C. J. W., Bagson, E. \& Aalangdong, I. O. (2013). Livelihood enhancement through ecotourism; a case of Mognori Ecovillage near Mole National Park, Damongo, Ghana. International Journal of Business and Social Science, 4(4), 128.

Kuuder, C.J. W., Bagson, E., and Aalangdong, I. O. (2013b). Assessment of visitor satisfaction in Mole National Park, Ghana. African Journal of Hospitality, Tourism and Leisure, 2(3) - (2013) ISSN: 2223-814X.

Manral, U. (2018). An Assessment of Phyto-Resource Availability and Community-Based Conservation of Natural Resources in Western Himalaya. The Ruffor Foundation. Journal of World Heritage Studies, Special Issue 2018. In Mountain Research and Development Vol 37 No 3 Aug 2017 310-322.

McGuigan, B. (2018). The Definition of a Leisure Traveler. Travel Tip, Leaf Group Updated April 24, 2018.

Mohapatra, P. P., Dash, P., Shekha, H., Palei, H.S., and Debata, S. (2017). Ecological and Social Aspects of Biodiversity Conservation in Sacred Groves of Bonai Forest Division, Odisha, India. December 2017. In book: Biodiversity conservation and Wildlife Management. North Orissa University. Project: Protection and Conservation of Sacred Groves of Bonai division in Sundargarh district of Orissa.

Mole National Park (2015). Mole Management. Wildlife Division of the Forestry Commission.

Nganso, T. B., Kyerematen, R. and Obeng-Ofori, D. (2011). "Impact of sacred groves on biodiversity conservation in Ghana." Current Trends In Ecology. 3. 1-10.

Osei-Bonsu, C. (2016). CEO Ghana Tourism Authority: Interview Tourism chapter from The Report: Ghana 2016. UNESCO World Heritage Centre. Mole National Park. 
Ostlie, N., Bowen, B., Zinda, C., Lupine, I., Ducay, T., and Hiker, M. (2020). 8 Responses to preserve the sacred lands of the greater Yellowstone ecosystem. In George Wuerthner's "Preserve the sacred lands of the Greater Yellowstone Ecosystem. The Wild life News by Januanuary $31 " 2020$.

Oyebamiji, U. A, (2019). Adventure in a Sacred Grove. Terra Incognita Discoverer Ethical Ecotours. December 8.

ParkNet (2003). Recreational Use of Land in the United States: Section V Educational Opportunities of Recreational Areas. ParkNet National Park Service. In Recreational Use of Land in the United States, Part Xi of the Report on Land Planning, 1938.

Polidor, A. (2004). Sacred Groves of India. Sacred Land Film Project. June, 1, 2004.

Possey, D. A. (1999): Indigenous people and the traditional resources right: A basis for equitable relationship, processing of workshop. Green College Centre for Environmental Policy and understanding, Oxford U. K. Pp. 90 - 92.

Salifu, W. (2013). "Exploring Local Belief Systems for the Benefit of Land Restoration: A Case Study of the Jaagbo Shrine Restoration in the Tolon/Kumbungu District of Northern Region, Ghana." United Nations University Land Restoration Training Programme.

Shaw, E. (2018). Common wildlife in Ghana. Travel Tips, Leaf Group Updated March 21.

Swamy, P.S., Kumar, M. and Sundarapandian, S.M. (2003). "Spirituality and Ecology of Sacred Groves in Tamil Nadu, India." Unaslyva 213, Vol. 54.

Telly, E. M. (2003): Developing the Jaagbo Sacred grove: In the Tolon - Kumbungu District, Unpublished.

Telly, E. M. (2006). "Sacred Groves, Rituals and Sustainable Community Development in Ghana." In Conserving Cultural and Biological Diversity: The Role of Sacred Natural Sites and Cultural Landscapes, edited by Thomas Schaaf and Cathy Lee. Paris: UNESCO.

UNDP / WTO. (1995): National Tourism Development Plan for Ghana 1996 - 2010: Integrated Tourism. Pp. $132-137$.

UNEP [United Nations Environment Programme] (2012). Keeping Track of Our Changing Environment: From Rio to Rio+20 (1992-2012). Nairobi: United Nations Environment Programme.

UNESCO [United Nations Education, Scientific, and Cultural Organization] (2018). "UNESCO Initiative on Heritage of Religious Interest."

UNESCO [United Nations Education, Scientific, and Cultural Organization] (2017). A New Roadmap for the Man and the Biosphere (MAB) Programme and Its World Network of Biosphere Reserves. Paris: UNESCO.

Verschuuren, B. and Brown, S. eds. (2019). Cultural and Spiritual Significance of Nature in Protected Areas: Governance, Management, and Policy. Abingdon, UK: Routledge.

Verschuuren, B. (2016). "Re-awakening the Power of Place.” In Asian Sacred Natural Sites: Philosophy and Practice in Protected Areas and Conservation, edited by Bas Verschuuren and Naoya Furuta, 1-14. London: Routledge.

World Bank Report (2017). World Travel and Tourism Council Report on Travel and Tourism Economic Impact Analysis in 2017. 1-20.

Wuerthner, G. (2020). Preserve the sacred lands of the Greater Yellowstone Ecosystem. The Wild life News. Januanuary 31.

Ziegler, Z (2019). Jachie and Jaagbo Groves of Ghana. Sacred Land Film Project. July 11. 


$\begin{array}{lll}\text { APPENDICES } & \\ \text { ACRONYMS } & \\ \text { GoG } & - & \text { Government of Ghana } \\ \text { NGSV } & - & \text { Northern Guinea Savannah Vegetation } \\ \text { UNESCO } & - & \text { United Nations Educational Scientific and Cultural Organization } \\ \text { CIPSEG } & - & \text { Cooperative Integrated Project on Savannah Eco - systems in Ghana. } \\ \text { EPA } & - & \text { Environmental Protection Agency } \\ \text { GTB } & - & \text { Ghana Tourist Board } \\ \text { WTO } & - & \text { World Tourist Organization } \\ \text { UNDP } & - & \text { United Nations Development Programme } \\ \text { FRMP } & - & \text { Forest Resource Management Project } \\ \text { IDA } & - & \text { International Development Agency } \\ \text { WRI } & - & \text { World Resource Institute } \\ \text { IUNC } & - & \text { International Union for Conservation of Nature } \\ \text { GACON } & - & \text { Ghana Association for Conservation of Nature } \\ \text { SGMC } & - & \text { Sacred Grove Management Committee } \\ \text { NGOs } & - & \text { Non-Governmental Organizations }\end{array}$

SURVEY INSTRUMEMT

TOPIC: EVALUATION OF THE POTENTIALS OF SCRED GROVES FOR DEVELOPMENT

\section{General Information}

Name of community

District:

of $\quad$ Respondent

Language:

Occupation Religion

Sex

.Marital

Educational Level

Status....

Age:

A: Identifying Interest Areas of Visitors to Groves

1. Do you have sacred groves in this area?

2. Do visitors often visit the grove?

(a) Yes

(a) Yes

3. What are the things that interest

a. History for the grove.

c. Religious rites carried out in the grove. b. Floral diversity of the grove.

d. Others

B: Custodian(s) / Ownership of Sacred Groves

4. How many sacred groves are in this community?

5. Who owns the grove?

6. Who in the community takes care of the grove?

7. How does an outsider access the sacred grove?

C: Value of Sacred Groves to Communities

8. Do you think the grove(s) is / are of my importance to you?

8. (a) If Yes, what are the benefits derived from them?

(a) $\operatorname{Yes}[$ ]

(b) No ( ) i.

ii.

9. Will you encourage the development of the grove into a tourist site or recreational facility? 2020 | Journal of Sustainable Tourism and Entrepreneurship/ Vol 1 No 3, 195-215 
why?

10. Will you accept the community or NGO's to develop the place? (a) Yes

11. What are the unique features of the grove (plants, animals, artifacts etc.)?

i.

ii.

\section{E: Identify Types and Uses of Plants in the Grove}

12. Are there any special types of plants / animals popular with visitors / community members in the grove?

(a) Yes

(b) $) \mathrm{No}$

13. What are the uses of these plants?

i.

ii

F: Project, Preserve and Conserve Plant and Animal Species That Live wild in the Grove

14. How do you maintain plant and animal species in the grove?

15. Do you allow people to cut fuel wood from the grove?

16. Are people allowed to hunt in the grove?

17. Are people allowed to farm in the grove?

(a) Yes

(a) Yes

(a) Yes

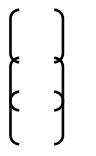

(b) No

(b) No

(b) No

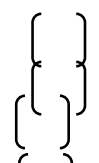

18. Do you normally protect the grove from bush fires in your community?

(b)

19. Are there rules that limit the movement of people to such area?

(a) Yes

(a)Yes

(b) No ( )

20. Are people punished for contradicting the rules governing the sacred area? (a)Yes No

20. (a) If Yes, how is it done?....

\section{G: Transform the Place as Tourist Centre}

21. If the grove is to be developed, what are the things you suggest to provide for tourist or community members?.

Appendix Table 1: Tree cover loss data for Ghana (Source: Global Forest Watch, 2020)

\begin{tabular}{|c|c|c|c|c|c|c|c|c|c|c|c|c|}
\hline $\begin{array}{l}\text { Tree } \\
\text { cover } \\
\text { thres } \\
\text { hold } \\
(\%)\end{array}$ & $\begin{array}{l}\text { Total } \\
\text { area } \\
\text { (ha) }\end{array}$ & $\begin{array}{l}\text { Tree } \\
\text { cover } \\
\text { Extent } \\
\text { in } \\
2000 \\
\text { (ha) }\end{array}$ & $\begin{array}{l}\% \\
\text { land } \\
\text { area }\end{array}$ & $\begin{array}{l}\text { Tree } \\
\text { cover } \\
\text { Extent } \\
\text { in } \\
2010 \\
\text { (ha) }\end{array}$ & $\begin{array}{l}\% \\
\text { land } \\
\text { area }\end{array}$ & $\begin{array}{l}\text { Tree } \\
\text { cover } \\
\text { Extent } \\
\text { in } \\
2018 \\
\text { (ha) }\end{array}$ & $\begin{array}{l}\% \\
\text { land } \\
\text { area }\end{array}$ & $\begin{array}{l}\text { Tree } \\
\text { cover } \\
\text { loss } \\
2001 \\
- \\
2018 \\
\text { (ha) }\end{array}$ & $\begin{array}{l}\% \\
\text { tree } \\
\text { cover } \\
\text { loss } \\
\text { since } \\
2000\end{array}$ & $\begin{array}{l}\text { Avg } \\
\text { tree } \\
\text { cover } \\
\text { loss/ } \\
\text { year } \\
\text { (ha) }\end{array}$ & $\begin{array}{l}\text { Avg } \\
\text { loss/ } \\
\text { year } \\
2001- \\
2010 \\
\text { (ha) }\end{array}$ & $\begin{array}{l}\text { Avg } \\
\text { loss/ } \\
\text { year } \\
2011 \\
- \\
2018 \\
\text { (ha) }\end{array}$ \\
\hline 10 & $\begin{array}{l}23878 \\
697\end{array}$ & $\begin{array}{l}18364 \\
317\end{array}$ & $\begin{array}{l}76.9 \\
0 \%\end{array}$ & $\begin{array}{l}17330 \\
468\end{array}$ & $\begin{array}{l}72.6 \\
0 \%\end{array}$ & $\begin{array}{l}16338 \\
336\end{array}$ & $\begin{array}{l}68.4 \\
0 \%\end{array}$ & $\begin{array}{l}1460 \\
431\end{array}$ & $\begin{array}{l}8.00 \\
\%\end{array}$ & $\begin{array}{l}8113 \\
5\end{array}$ & 46830 & $\begin{array}{l}1240 \\
17\end{array}$ \\
\hline 15 & $\begin{array}{l}23878 \\
697\end{array}$ & $\begin{array}{l}13308 \\
380\end{array}$ & $\begin{array}{l}55.7 \\
0 \%\end{array}$ & $\begin{array}{l}13650 \\
441\end{array}$ & $\begin{array}{l}57.2 \\
0 \%\end{array}$ & $\begin{array}{l}12720 \\
839\end{array}$ & $\begin{array}{l}53.3 \\
0 \%\end{array}$ & $\begin{array}{l}1373 \\
941\end{array}$ & $\begin{array}{l}10.30 \\
\%\end{array}$ & $\begin{array}{l}7633 \\
0\end{array}$ & 44434 & $\begin{array}{l}1162 \\
00\end{array}$ \\
\hline 20 & $\begin{array}{l}23878 \\
697\end{array}$ & $\begin{array}{l}82495 \\
10\end{array}$ & $\begin{array}{l}34.5 \\
0 \%\end{array}$ & $\begin{array}{l}90602 \\
80\end{array}$ & $\begin{array}{l}37.9 \\
0 \%\end{array}$ & $\begin{array}{l}82661 \\
25\end{array}$ & $\begin{array}{l}34.6 \\
0 \%\end{array}$ & $\begin{array}{l}1191 \\
773\end{array}$ & $\begin{array}{l}14.40 \\
\%\end{array}$ & $\begin{array}{l}6621 \\
0\end{array}$ & 39762 & $\begin{array}{l}9926 \\
9\end{array}$ \\
\hline 25 & $\begin{array}{l}23878 \\
697\end{array}$ & $\begin{array}{l}79378 \\
98\end{array}$ & $\begin{array}{l}33.2 \\
0 \%\end{array}$ & $\begin{array}{l}85536 \\
64\end{array}$ & $\begin{array}{l}35.8 \\
0 \%\end{array}$ & $\begin{array}{l}77743 \\
64\end{array}$ & $\begin{array}{l}32.6 \\
0 \%\end{array}$ & $\begin{array}{l}1170 \\
027\end{array}$ & $\begin{array}{l}14.70 \\
\%\end{array}$ & $\begin{array}{l}6500 \\
2\end{array}$ & 39073 & $\begin{array}{l}9741 \\
3\end{array}$ \\
\hline 30 & $\begin{array}{l}23878 \\
697\end{array}$ & $\begin{array}{l}69720 \\
40\end{array}$ & $\begin{array}{l}29.2 \\
0 \%\end{array}$ & $\begin{array}{l}70507 \\
75\end{array}$ & $\begin{array}{l}29.5 \\
0 \%\end{array}$ & $\begin{array}{l}63313 \\
29\end{array}$ & $\begin{array}{l}26.5 \\
0 \%\end{array}$ & $\begin{array}{l}1089 \\
185\end{array}$ & $\begin{array}{l}15.60 \\
\%\end{array}$ & $\begin{array}{l}6051 \\
0\end{array}$ & 36974 & $\begin{array}{l}8993 \\
1\end{array}$ \\
\hline
\end{tabular}

2020 | Journal of Sustainable Tourism and Entrepreneurship/ Vol 1 No 3, 195-215 


\begin{tabular}{|c|c|c|c|c|c|c|c|c|c|c|c|c|}
\hline $\begin{array}{l}\text { Tree } \\
\text { cover } \\
\text { thres } \\
\text { hold } \\
(\%)\end{array}$ & $\begin{array}{l}\text { Total } \\
\text { area } \\
\text { (ha) }\end{array}$ & $\begin{array}{l}\text { Tree } \\
\text { cover } \\
\text { Extent } \\
\text { in } \\
2000 \\
\text { (ha) }\end{array}$ & $\begin{array}{l}\% \\
\text { land } \\
\text { area }\end{array}$ & $\begin{array}{l}\text { Tree } \\
\text { cover } \\
\text { Extent } \\
\text { in } \\
2010 \\
\text { (ha) }\end{array}$ & $\begin{array}{l}\% \\
\text { land } \\
\text { area }\end{array}$ & $\begin{array}{l}\text { Tree } \\
\text { cover } \\
\text { Extent } \\
\text { in } \\
2018 \\
\text { (ha) }\end{array}$ & $\begin{array}{l}\% \\
\text { land } \\
\text { area }\end{array}$ & $\begin{array}{l}\text { Tree } \\
\text { cover } \\
\text { loss } \\
2001 \\
- \\
2018 \\
\text { (ha) }\end{array}$ & $\begin{array}{l}\% \\
\text { tree } \\
\text { cover } \\
\text { loss } \\
\text { since } \\
2000\end{array}$ & $\begin{array}{l}\text { Avg } \\
\text { tree } \\
\text { cover } \\
\text { loss/ } \\
\text { year } \\
\text { (ha) }\end{array}$ & $\begin{array}{l}\text { Avg } \\
\text { loss/ } \\
\text { year } \\
2001- \\
2010 \\
\text { (ha) }\end{array}$ & $\begin{array}{l}\text { Avg } \\
\text { loss/ } \\
\text { year } \\
2011 \\
- \\
2018 \\
\text { (ha) }\end{array}$ \\
\hline 50 & $\begin{array}{l}23878 \\
697\end{array}$ & $\begin{array}{l}42636 \\
01\end{array}$ & $\begin{array}{l}17.9 \\
0 \%\end{array}$ & $\begin{array}{l}36191 \\
52\end{array}$ & $\begin{array}{l}15.2 \\
0 \%\end{array}$ & $\begin{array}{l}31704 \\
20\end{array}$ & $\begin{array}{l}13.3 \\
0 \%\end{array}$ & $\begin{array}{l}7454 \\
62\end{array}$ & $\begin{array}{l}17.50 \\
\%\end{array}$ & $\begin{array}{l}4141 \\
5\end{array}$ & 29673 & $\begin{array}{l}5609 \\
2\end{array}$ \\
\hline 75 & $\begin{array}{l}23878 \\
697\end{array}$ & $\begin{array}{l}20779 \\
8\end{array}$ & $\begin{array}{l}0.90 \\
\%\end{array}$ & $\begin{array}{l}16945 \\
7\end{array}$ & $\begin{array}{l}0.70 \\
\%\end{array}$ & $\begin{array}{l}15660 \\
7\end{array}$ & $\begin{array}{l}0.70 \\
\%\end{array}$ & $\begin{array}{l}6036 \\
6\end{array}$ & $\begin{array}{l}29.10 \\
\%\end{array}$ & 3354 & 4752 & 1606 \\
\hline
\end{tabular}

Appendix Table 2: Protected areas data: Ghana

Protected areas (2017)

Percentage

Terrestrial

protected

$\%$ of total land area

areas,

Marine

protected

15.1

$\%$ of territorial waters

Data Source: Global Forest Watch (1995-2020)

Appendix Table 3: Tree cover data for subnational administrative areas in Ghana

\begin{tabular}{|c|c|c|c|c|c|c|c|c|c|c|c|c|c|c|}
\hline 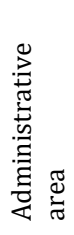 & 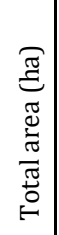 & 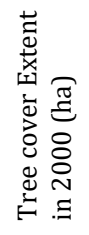 & 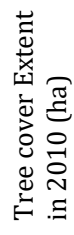 & 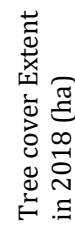 & 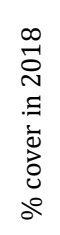 & 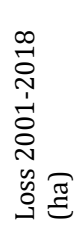 & 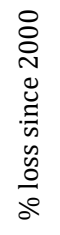 & 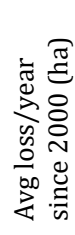 & 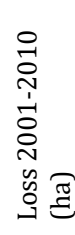 & 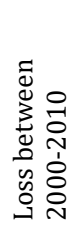 & 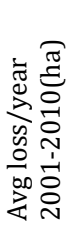 & 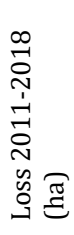 & 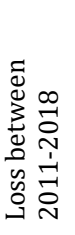 & 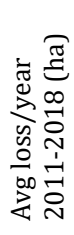 \\
\hline 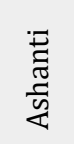 & 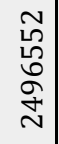 & $\begin{array}{l}\stackrel{0}{\overrightarrow{1}} \\
\stackrel{\hat{N}}{\stackrel{\leftrightarrow}{\sim}}\end{array}$ & 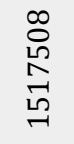 & 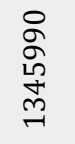 & 扁 & 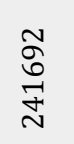 & هి & 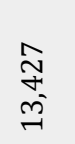 & $\underset{⿱ 亠}{\stackrel{+}{0}}$ & i̊ & م્ & $\begin{array}{l}\infty \\
\stackrel{-}{n} \\
\stackrel{-}{-}\end{array}$ & $\stackrel{\circ}{\stackrel{े}{F}}$ & $\underset{\substack{+\multirow{N}{*}{}}}{-1}$ \\
\hline 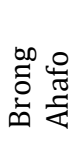 & 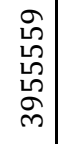 & \begin{tabular}{l} 
के \\
\multirow{2}{\circ}{} \\
$\sigma$ \\
$\sigma$
\end{tabular} & $\begin{array}{l}\text { N } \\
\stackrel{m}{m} \\
\exists \\
\exists\end{array}$ & 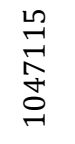 & \&̊ㅇㅇ & $\stackrel{\stackrel{L}{N}}{\stackrel{N}{N}}$ & $\stackrel{\stackrel{\leftrightarrow}{+}}{\sim}$ & $\begin{array}{l}8 \\
8 \\
\circ \\
\end{array}$ & 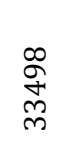 & $\stackrel{\circ}{+}$ & $\begin{array}{c}0 \\
\stackrel{n}{n} \\
m \\
m\end{array}$ & $\underset{\widetilde{N}}{\stackrel{F}{\sigma}}$ & ळి & \begin{tabular}{l}
$\infty$ \\
$\infty$ \\
\multirow{F}{*}{}
\end{tabular} \\
\hline 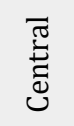 & $\begin{array}{l}-7 \\
\overrightarrow{1} \\
\infty \\
\stackrel{0}{0} \\
o\end{array}$ & 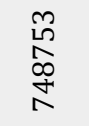 & $\begin{array}{l}\underset{N}{\alpha} \\
\underset{N}{*}\end{array}$ & $\begin{array}{l}\tilde{\sigma} \\
\text { oे } \\
\text { ob }\end{array}$ & ㅇํㅇ & 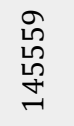 & ڤे & $\begin{array}{l}\hat{\infty} \\
0 \\
\infty\end{array}$ & $\underset{\stackrel{N}{A}}{\vec{b}}$ & ळొ & $\stackrel{m}{\stackrel{m}{\sigma}}$ & $\begin{array}{l}\mathbb{N} \\
\infty \\
\infty \\
\infty\end{array}$ & 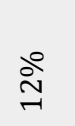 & 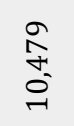 \\
\hline 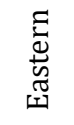 & 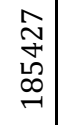 & $\begin{array}{l}\text { ơ } \\
\text { హे } \\
\text { బू }\end{array}$ & $\begin{array}{l}\vec{n} \\
\stackrel{\Xi}{\sigma} \\
\text { a }\end{array}$ & $\begin{array}{l}\infty \\
\infty \\
\infty \\
\infty \\
0 \\
\infty\end{array}$ & $\stackrel{\stackrel{f}{f}}{\circ}$ & $\begin{array}{l}8 \\
8 \\
0 \\
0 \\
+1\end{array}$ & 욤 & $\underset{\infty}{\stackrel{+}{+}}$ & $\begin{array}{l}\hat{n} \\
\text { مे } \\
\text { के }\end{array}$ & $\stackrel{\circ}{+}$ & $\begin{array}{l}\stackrel{\circ}{\circ} \\
\stackrel{2}{m}\end{array}$ & 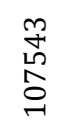 & 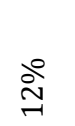 & 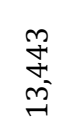 \\
\hline 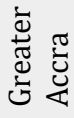 & 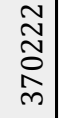 & $\begin{array}{l}\hat{N} \\
\text { N}\end{array}$ & 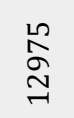 & 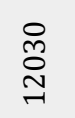 & ஓे & $\begin{array}{l}\infty \\
\stackrel{\infty}{7} \\
\end{array}$ & ஷे & ร & $\underset{\infty}{\vec{J}}$ & $\stackrel{\circ}{\stackrel{\circ}{\exists}}$ & పా & 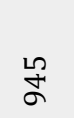 & $\stackrel{\circ}{\wedge}$ & $\stackrel{\infty}{\exists}$ \\
\hline 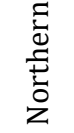 & 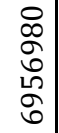 & $\frac{\nwarrow}{\xi}$ & 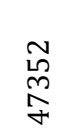 & 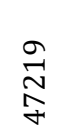 & 암 & $\underset{\sigma}{\sigma}$ & ळे̀ & $\sigma$ & $\begin{array}{l}0 \\
\text { I } \\
\end{array}$ & iे & กี & $\stackrel{m}{\rightarrow}$ & ठे & $\Rightarrow$ \\
\hline
\end{tabular}

2020 | Journal of Sustainable Tourism and Entrepreneurship/ Vol 1 No 3, 195-215 


\begin{tabular}{|c|c|c|c|c|c|c|c|c|c|c|c|c|c|c|}
\hline 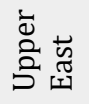 & $\begin{array}{l}0 \\
\stackrel{0}{0} \\
\mathbb{b} \\
\infty\end{array}$ & $\stackrel{\infty}{\sim}$ & $\stackrel{\infty}{\stackrel{\infty}{\sim}}$ & $\stackrel{\infty}{\stackrel{\infty}{N}}$ & ठ̊ & $\underset{\sim}{\rightleftarrows}$ & $\stackrel{\circ}{\triangleright}$ & - & $\stackrel{\Xi}{\sqsupset}$ & $\stackrel{\circ}{\curvearrowright}$ & - & 0 & ठ̊ & ' \\
\hline 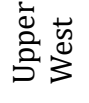 & $\begin{array}{l}\hat{m} \\
\stackrel{2}{\infty} \\
\stackrel{-}{-}\end{array}$ & $\tilde{6}$ & న & $\vec{\Omega}$ & ठे & เి & ১े & $m$ & $\stackrel{\infty}{\llcorner}$ & ふু̊ & 0 & - & ठ̊ & ' \\
\hline$\frac{\pi}{0}$ & 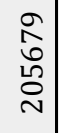 & $\begin{array}{l}\hat{f} \\
\stackrel{+}{L} \\
\stackrel{f}{+}\end{array}$ & $\begin{array}{l}\circ \\
\infty \\
\infty \\
\stackrel{0}{\alpha} \\
\stackrel{f}{f}\end{array}$ & 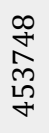 & $\stackrel{\text { సे }}{\text { No }}$ & $\begin{array}{l}\text { } \\
\stackrel{D}{ } \\
\stackrel{N}{ }\end{array}$ & $\stackrel{2}{\wedge}$ & $\begin{array}{l}\text { ָे } \\
\text { - } \\
-\end{array}$ & 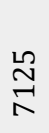 & 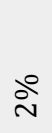 & $\stackrel{m}{\wedge}$ & $\underset{\underset{N}{N}}{\vec{J}}$ & เे & $\begin{array}{l}\infty \\
\stackrel{0}{N} \\
\stackrel{N}{*}\end{array}$ \\
\hline $\begin{array}{l}\tilde{\Xi} \\
\text { एँّ } \\
3\end{array}$ & 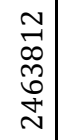 & 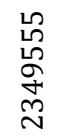 & $\begin{array}{l}\stackrel{2}{N} \\
\text { S } \\
\stackrel{N}{N}\end{array}$ & 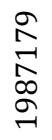 & $\frac{\stackrel{0}{\infty}}{\infty}$ & 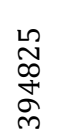 & 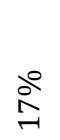 & $\begin{array}{l}L \\
\tilde{\omega} \\
\sigma \\
\vec{N}\end{array}$ & $\begin{array}{l}\stackrel{\Im}{N} \\
\text { م⿱ } \\
\stackrel{2}{\sim}\end{array}$ & $\stackrel{2}{\wedge}$ & 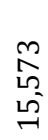 & 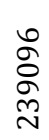 & $\stackrel{\circ}{\stackrel{ }{r}}$ & $\begin{array}{l}\hat{\infty} \\
\infty \\
\infty \\
\text { N. }\end{array}$ \\
\hline
\end{tabular}

Table 3 Source: Tree cover loss: Hansen/UMD/USGS/NASA via Global Forest Watch, 2020.

Appendix Table 4 Biodiversity data: Ghana

\begin{tabular}{|lr|}
\hline Animal / plant group & $\begin{array}{r}\text { Species } \\
\text { count }\end{array}$ \\
\hline Birds & 681 \\
\hline Amphibians & 89 \\
\hline Reptiles & 182 \\
\hline Fishes & 694 \\
\hline Mammals & 257 \\
\hline Vascular plants & 3725 \\
\hline Data Source: Global Forest Watch (1995-2020). \\
\hline
\end{tabular}

Appendix Table 5: Conservation data on threatened species in Ghanaian protected areas

Taxa Species count

$\begin{array}{ll}\text { Threatened mammals (2018) } & 21\end{array}$

Threatened birds (2018) 23

$\begin{array}{lr}\text { Threatened fishes (2018) } & 58\end{array}$

$\begin{array}{ll}\text { Threatened higher plants (2018) } & 119\end{array}$

Data Source: Global Forest Watch (1995-2020). 